\title{
The Effect of the Use of Jakcard on the Decision of Visiting the Ragunan Wildlife Park in Jakarta
}

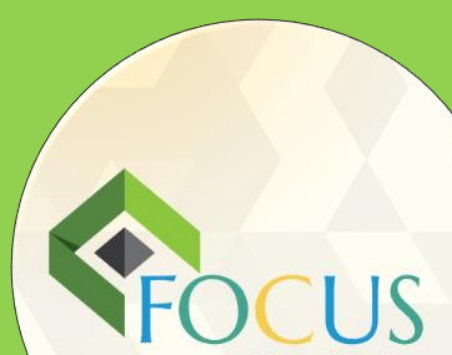

Journal of Social Studies

\section{Muhammad Dzakir Alif}

Universitas Indraprasta PGRI

Jl. Raya Tengah No.80, RT.6/RW.1,

Gedong, Ps. Rebo, Kota Jakarta Timur,

DKI Jakarta 13760.

+62 895-3930-32778

\section{Endah Widati}

Universitas Indraprasta PGRI

Jl. Raya Tengah No.80, RT.6/RW.1,

Gedong, Ps. Rebo, Kota Jakarta Timur,

DKI Jakarta 13760.

\section{Hamzah Robbani}

Universitas Indraprasta PGRI

Jl. Raya Tengah No.80, RT.6/RW.1,

Gedong, Ps. Rebo, Kota Jakarta Timur,

DKI Jakarta 13760.

21pb01004@student.kuis.edu.my

\section{DOI}

https://doi.org/10.37010/fcs.v1i2.355

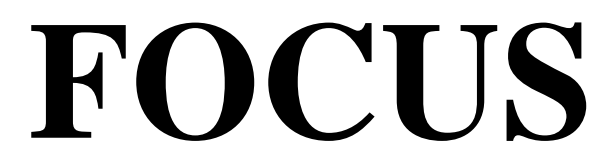

\section{Journal of Social Studies}

\section{Vol. 1 No. 2 AGUSTUS 2021}

\section{Pengaruh Penggunaan Jakcard terhadap Putusan Kunjungan Taman Margasatwa Ragunan di Jakarta}

\begin{abstract}
The purpose of this study was to determine whether or not the use of jakcard had an effect on the decision to visit the Ragunan Wildlife Park in Jakarta. The research method used in

this paper is a causal associative method with a quantitative approach. Data collection techniques used are questionnaires, interviews and observations. The number of respondents is taken based on people who have an active JakCard card and have visited TMR at least 1 time as many as 100 people. Based on the results of the study, it was found that there was an effect of using a jakcard on the decision to visit the Ragunan Wildlife Park in Jakarta with a coefficient of determination of $42.92 \%$ and the remaining $58.08 \%$ determined by the contribution of other factors not examined in this study.
\end{abstract}

Keywords: use of jakcard, visit decision, Ragunan Wildlife Park

Abstrak

Tujuan penelitian ini adalah untuk mengetahui ada tidaknya pengaruh penggunaan jakcard terhadap putusan kunjungan Taman Margasatwa Ragunan di Jakarta. Metode penelitian yang digunakan dalam penulisan ini adalah metode asosiatif kausal dengan pendekatan kuantitatif.

Teknik pengumpulan data yang digunakan adalah kuesioner, wawancara dan observasi. Adapun jumlah responden diambil berdasarkan orang yang memiliki kartu JakCard aktif dan pernah berkunjung ke TMR min 1 kali sebanyak 100 orang. Berdasarkan hasil penelitian, didapat bahwa terdapat pengaruh penggunaan jakcard terhadap putusan kunjungan Taman

Margasatwa Ragunan di Jakarta dengan nilai koefisien determinasi sebesar 42,92\% dan sisanya 58,08\% ditentukan oleh kontribusi faktor lain yang tidak diteliti dalam penelitian ini.

Kata kunci: penggunaan Jakcard, putusan kunjungan, Taman Margasatwa Ragunan 


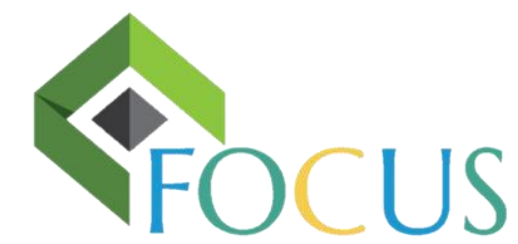

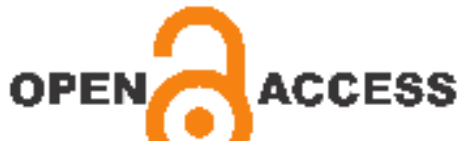

PENDAHULUAN

Pada tahun 1999 tepatnya pada tanggal 28 Oktober dan pada tanggal 1 November tahun 1999 Indonesia pernah mencetak serta menerbitkan uang dengan berbahan plastic atau polymer untuk alat pembayaran di Indonesia. Setelah terjadinya banyak perubahan pada alat permbayaran berupa uang kertas dan logam di Indonesia dengan adanya campur tangan dari kecerdasan buatan (AI) tersebut maka muncul lah sistem pembayaran baru berbasis teknologi berupa E-money (uang elektronik). Uang elektronik ini sendiri memiliki 2 jenis yakni berbasis chip atau kartu fisik dan berbasis server. Berbasis kartu fisik dikeluarkan oleh beberapa penyedia layanan seperti bank.

Beberapa bank mengeluarkan produk uang elektronik seperti Tapcash yang dikeluarkan oleh bank BNI, E-money dikeluarkan oleh bank Mandiri, Flazz dikeluarkan oleh bank BCA, Brizzi dikeluarkan oleh bank BRI dan Jakcard dikeluarkan oleh bank DKI sebagai alat pembayaran nontunai. Kartu Jakcard ini dapat digunakan untuk berbagai transaksi di tempat-tempat dan perusahaan yang telah bekerja sama dengan bank DKI. Kepraktisan kartu Jakcard ini bisa dimanfaatkan warga untuk salah satu pembayaran tiket transjakarta. Selain transjakarta, kartu Jakcard dapat digunakan dibeberapa tempat wisata yang dikelola oleh pemprov DKI Jakarta seperti Taman Margasatwa Ragunan dan Tugu Monumen Nasional (Monas). Pada 27 April 2016, Taman Margasatwa Ragunan telah menerapkan kartu Jakcard sebagai alat pembayaran untuk masuk Taman Margasatwa Ragunan.

Dari sekian banyak tempat wisata di Jabodetabek, yang menjadi salah satu tujuan wisata favorit keluarga adalah obyek wisata pendidikan, alam dan lingkungan. Di DKI Jakarta, tepatnya di Pasar Minggu Jakarta Selatan terdapat salah satu tempat rekreasi favorit keluarga, yaitu Taman Margasatwa Ragunan. Taman Margasatwa Ragunan menjadi salah satu obyek wisata favorit karena tempatnya cocok untuk untuk berkumpul dengan keluarga, teman dan orang terdekat. Di Taman Margasatwa Ragunan, pengunjung tidak hanya dapat melihat satwa dan pepohonan saja, namun pengunjung juga dapat bermain dan piknik bersama keluarga karena disana juga disediakan area penyewaan sepeda dan mobil kereta untuk pengunjung berkeliling di sekitar Taman Margasatwa Ragunan.

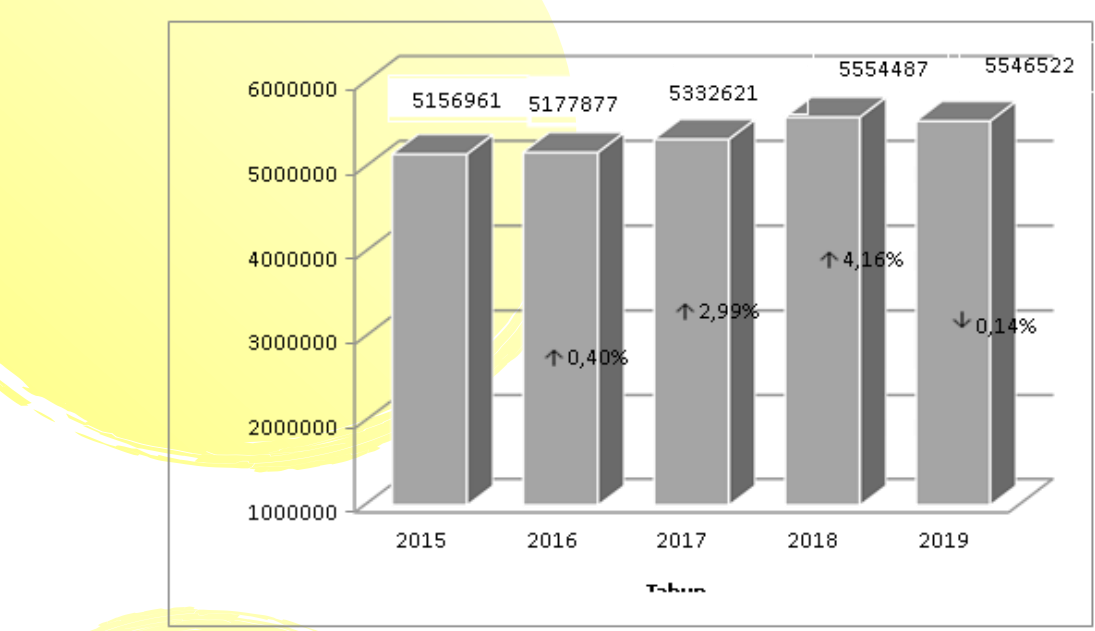

Sumber: Official Facebook Taman Margasatwa Ragunan (2018 \& 2019)

Gambar 1. Data Jumlah Wisatawan Taman Margasatwa Ragunan Tahun 2015-2019

Berdasarkan data pengunjung yang telah disampaikan pada gambar 1, dapat diketahui bahwa jumlah pengunjung obyek wisata Taman Margasatwa Ragunan mengalami kenaikan selama lima tahun terakhir. Dengan kenaikan tersebut, pengelola obyek wisata Taman Margasatwa Ragunan tetap harus selalu melakukan 
pembaharuan atau pengembangan untuk meningkatkan tingkat keputusan kunjungan, karena meskipun fasilitas dan pelayanan yang disediakan pada saat itu dapat dikatakan baik.

Taman Margasatwa Ragunan perlu mengetahui pengaruh dari penerapan kartu Jakcard sebagai alat pembayaran tiket masuk untuk reputasi objek wisatanya semakin positif di mata masyarakat pada umumnya dan pengunjung pada khususnya, untuk mendeteksi dan mengetahui dengan baik tentang jalannya proses bisnis, untuk mendorong terciptanya loyalitas pengunjung, meningkatkan keuntungan, mengetahui secara tepat di mana harus melakukan perubahan dan perbaikan terus menerus dalam upayanya memuaskan pengunjung, menentukan perubahan yang dilakukan yang mengarah pada perbaikan.

Berdasarkan fenomena tersebut maka akan diteliti terkait adakah pengaruh yang signifikan antara Pengaruh Penggunaan Jakcard terhadap Putusan Kunjungan Taman Margasatwa Ragunan di Jakarta. Penelitian ini bertujuan untuk mengetahui pengaruh kartu Jakcard terhadap putusan kunjungan di Taman Margasatwa Ragunan.

\section{METODE PENELITIAN}

Pada Penelitian ini menggunakan penelitian asosiatif kausal (sebab akibat) dengan pendekatan kuantitatif. Dengan menggunakan metode penelitian akan diketahui hubungan yang signifikan antara variabel penggunaan jakcard dengan variabel putusan kunjungan. Survei dilakukan dengan cara penyebaran kuesioner kepada pengunjung yang berkunjung ke objek wisata Taman Margasatwa Ragunan.

Berdasarkan penelitian ini, yang menjadi sasaran populasi adalah pemegang kartu JakCard yang pernah berkunjung ke Taman Margasatwa Ragunan. Populasi dalam penelitian ini tidak diketahui jumlahnya maka dianggap sebagai populasi tidak terbatas karena jumlah pemegang kartu JakCard yang memutuskan berkunjung ke Taman Margasatwa Ragunan tidak diketahui jumlahnya. Maka dari itu, untuk populasinya dihitung dari data jumlah pengguna aktif di akhir tahun 2018 sebanyak 187.000 pengguna kemudian di kali persentase jumlah pengunjung Taman Margasatwa Ragunan pada tahun 2019 terhadap jumlah total pengunjung destinasi wisata di DKI Jakarta. Dari jumlah pengunjung tersebut dihitung persentase pengunjung TMR, maka didapat sebesar adalah $15,15 \%$. Dengan demikian populasi tidak terbatas ini dapat dilihat dari jumlah pengguna JakCard aktif sebanyak 187,000 dikali 15,15\% sebanyak 758,000 pengunjung, besar sampel minimal dari 28.330 populasi dengan margin error $10 \%$ dan tingkat kepercayaan $90 \%$, maka sampel yang digunakan sebanyak 100. Teknik analisis data dilakukan dengan cara kuesioner, wawancara dan dokumentasi. Untuk mendapatkan kualitas data, peneliti melakukan validitas data dengan melakukan analisis pada faktor keabsahan data (validitas data).

\section{HASIL DAN PEMBAHASAN}

\section{Hasil}

Berdasarkan hasil olah data yang dilakukan, didapatkan nilai ttabel sebesar $=1,6605$ dan thitung sebesar $=11,3524$. Adapun nilai regresinya adalah $\hat{Y}=6,8258+0,8571 \mathrm{X}$. Dari hasil perbandingan tersebut menunjukan thitung lebih besar dari ttabel atau 11,3524 > 1,6605 maka H0 ditolak dan Ha diterima. Hal ini membuktikan adanya pengaruh Penggunaan Jakcard terhadap Putusan Kunjungan di Taman Margasatwa Ragunan.

Adapun bersadarkan uji Keberartian Regresi Linier (Uji F) didapatkan nilai Fhitung sebesar $=73.6842$, dan Ftabel sebesar $=3,94$. Berdasarkan pernyataan tersebut dapat disimpulkan bahwa Fhitung $>$ Ftabel $(73,6842$

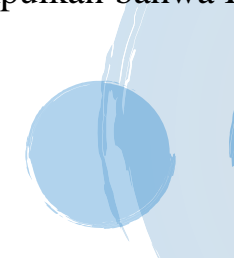




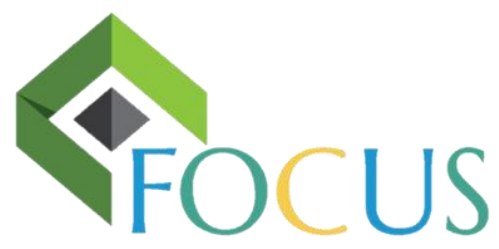

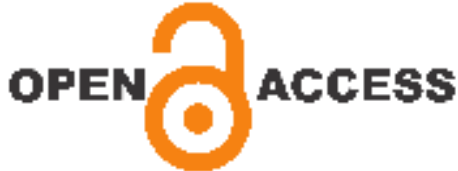

> 3,94), sehingga Ho ditolak dan disimpulkan terdapat pengaruh yang signifikan antara Penggunaan Jakcard (X) terhadap Putusan Kunjungan (Y).

\section{Pembahasan}

Berdasarkan hasil analisis data diatas, maka dapat diartikan bahwa terdapat pengaruh yang signifikan antara Penggunaan Jakcard terhadap Putusan Kunjungan. Hal ini dibuktikan dari hasil perhitungan analisis regresi sederhana yaitu $\mathrm{Y}=6,8258+0,8571 \mathrm{x}$ yang menghasilkan nilai koefisien yang positif Penggunaan Jakcard terhadap Putusan Kunjungan yang dirasakan secara berkesinambungan dari hari ke hari dimana jika variabel $\mathrm{X}$ (Penggunaan Jakcard) naik turun maka variabel (Putusan Kunjungan) juga naik turun.

Dan, dari hasil perhitungan koefisien korelasi didapat hasil 0,5336 yang artinya ada pengaruh yang rendah antara variable Penggunaan Jakcard (X) dengan Putusan Kunjungan (Y), dan berdasarkan tabel nilai interprestasi koefisien korelasi nilai hubungan korelasinya yang tinggi dan saling berhubungan.

Berdasarkan perhitungan koefisien determinasi (KD) Penggunaan Jakcard berkontribusi sebesar 48.92\% dan sisanya sebesar 58,08\% dipengaruhi oleh variabel - variabel lain. Dari pengujian hipotesis uji t didapat bahwa terdapat pengaruh yang signifikan Penggunan Jakcard terhadap Putusan Kunjungan, yang dimana nilai thitung sebesar 11,3524 dan ttabel sebesar 1,6605 sehingga dapat disimpukan terdapat pengaruh Penggunaan Jakcard (X) terhadap Putusan Kunjungan (Y).

Berdasarkan hasil uji hipotesis keberartian antara variabel Penggunaan Jakcard X terhadap variabel Putusan Kunjungan Y diperoleh Fhitung > Ftabel $(78,0397>3,89)$, sehingga disimpulkan terdapat pengaruh yang signifikan antara variabel $(\mathrm{X})$ terhadap putusan kunjungan $(\mathrm{Y})$.

Berdasarkan hasil uji hipotesis keberartian antara variabel X dan terhadap variabel Y diperoleh Fhitung > Ftabel $(78,0397>3,89)$, sehingga disimpulkan terdapat pengaruh yang signifikan Penggunaan JakCard X secara bersama-sama terhadap Putusan Kunjungan (Y).

Berdasarkan hasil uji t untuk variabel $\mathrm{X}$ yang dilakukan diperoleh thitung lebih besar dari ttabel $(11,3524>1,6605)$ sehingga disimpulkan terdapat korelasi positif yang signifikan antara Penggunaan Jakcard X dan Putusan Kunjungan (Y).

Berdasarkan hasil uji F yang dilakukan diperoleh diperoleh Fhitung <Ftabel $(73,6842>3,94)$ pada taraf signifikasi 0,1 , sehingga disimpulkan bahwa secara bersama-sama tidak terdapat korelasi (hubungan) yang signifikan antara Penggunaan Jakcard (X) dan Putusan Kunjungan (Y).

\section{PENUTUP}

Dari hasil penelitian ini dapat disimpulkan bahwa terdapat pengaruh penggunaan kartu jakcard terhadap putusan kunjungan TMR di Jakarta sebesar 65,51\% dengan tingkat koefisien determinasi 42,92\%. Dari hasil yang telah diperoleh oleh peneliti menunjukkan bahwa thitung lebih besar dari ttabel atau 11,3524>1,6605 maka H0 ditolak dan Ha diterima. Hal ini membuktikan adanya pengaruh Penggunaan Jakcard terhadap Putusan Kunjungan di Taman Margasatwa Ragunan.

Berdasarkan hasil penelitian yang telah dilakukan oleh peneliti mengenai penggunaan Jakcard terhadap putusan kunjungan, maka peneliti menyarankan agar Pemerintah DKI Jakarta untuk lebih efektif dan efisien dalam mendistribusikan Jakcard sebagai alat transaksi nontunai serta menambah sarana Jakcard untuk meningkatkan kenyamanan dan keamanan.

\section{DAFTAR PUSTAKA}


Husein, U. (2009). Metode Penelitian Untuk Skripsi dan Tesis Bisnis. Jakarta: Rajawali Persada.

Indonesia, B. (2011, 03 14). Sistem Pembayaran di Indonesia. Retrieved 12 20, 2019, from Bank Indonesia:

https://www.bi.go.id/id/E404.aspx?RequestedUrl=https://www.bi.go.id:443/id/ sistem-pembayaran/diindonesia/Contents/\%20Default.aspx

Indonesia, P. P. (2014). BUMN. Retrieved 12 20, 2019, from PNRI: http://www.pnri.co.id/id/index.php/ruanglingkup-usaha/smart-card/102- smart-card

ListField, R., \& Negret, F. M. (1994). Modernizing Payment Systems in Emerging Economies. The World Bank: Financial Sector Development Department.

Marpaung, H. (2002). Pengetahuan Kepariwisataan. Bandung: Alfabeta.

Ng-Kruelle , G., \& Swatman, P. A. (2006). E-Ticketing Strategy and Implementation in an Open Access System: The case of Deutsche Bahn. School of Computing and Information Science, 1.

Sugiyono. (2017). Metode Penelitian Kuantitatif, Kualitatif, dan R\&D. Bandung: Alfabeta, CV.

Ramadani, L. (2016). Pengaruh Penggunaan Kartu Debit dan Uang Elektronik (E-Money) Terhadap Pengeluaran Konsumsi Mahasiswa. Jurnal Ekonomi \& Studi Pembangunan, 3. 